\title{
ИЗУЧЕНИЕ ОСОБЕННОСТЕЙ ГУМОРАЛЬНОГО ИММУННОГО ОТВЕТА К НОВОЙ КОРОНАВИРУСНОЙ ИНФЕКЦИИ COVID-19 СРЕДИ МЕДИЦИНСКИХ РАБОТНИКОВ
}

\author{
И.Д. Решетникова ${ }^{1,2}$, Ю.А. Тюрин ${ }^{1,3}$, Е.В. Агафонова ${ }^{1,3}$, С.Н. Куликов ${ }^{1}$, \\ Г.Ф. Гилязутдинова ${ }^{1}$, Д.В. Лопушов ${ }^{3,4}$, Н.Д. Шайхразиева ${ }^{4}$, Г.Ш. Исаева ${ }^{1,3}$, \\ В.Б. Зиатдинов ${ }^{1}$
}

${ }^{1}$ ФБУН Казанский НИИ эпидемиологии и микробиологии Роспотребнадзора, г. Казань, Россия

${ }^{2}$ ФГАОУ ВО Казанский (Приволжсккий) федеральный университет, г. Казань, Россия

${ }_{3}^{3}$ ФГБОУ ВО Казанский государственный медицинский университет, г. Казань, Россия

${ }^{4}$ Казанская государственная медицинская академия - филиал ГБОУ ДПО, г. Казань, Россия

Резюме. Актуальность. С начала эпидемии в Китае появились сообщения о внутрибольничных случаях инфицирования SARS-CoV-2, в том числе и среди медицинских работников. Исследования напряженности гуморального иммунного ответа к вирусу SARS-CoV-2 среди медицинских работников, имеющих высокий риск профессионального контакта с больными COVID-19, приобретают особую важность. Цель исследования - изучить серопревалентность и особенности гуморального иммунного ответа на вирус SARS-CoV-2 среди медицинских работников. Материалы и методы. Методом случайной выборки в исследование включили 61 медицинского работника из многопрофильного стационара г. Казани, который был перепрофилирован для оказания медицинской помощи больным новой коронавирусной инфекцией. Группу контроля составили 60 немедицинских работников. Для определения IgG использовался твердофазный ИФА. Статистическая обработка результатов проводилась с применением программного обеспечения MS Excel. Рассчитана ошибка относительной величины $(\mathrm{M} \pm \mathrm{m})$ и $95 \%$ доверительный интервал частоты встречаемости. Для оценки достоверности различий применяли критерий Стьюдента (t-критерий) для независимых выборок. Достоверными считали различия при $\mathrm{p}<0,05 \%$. Результаты и обсуждение. Доля серопозитивных к SARS-CoV-2 в основной группе составила 45,9\%, в контрольной группе $-21,7 \%$. У серопозитивных к вирусу SARS-CoV-2 медицинских работников доля бессимптомных форм COVID-19 составила 18,5\%, легких форм - 53,6\%, среднетяжелых и тяжелых форм - 25\%; выявлено два варианта формирования гуморального иммунного ответа: синхронный с параллельной элиминацией $\operatorname{IgG}$ и $\operatorname{IgM~антител~(группа~«элиминирующих»~антитела»)~и~параллельным~увеличением~IgG~и~IgM~(группа~}$ «повышающих» антитела). В группе серопозитивных количество лиц, «повышающих» антитела, превалировала над группой лиц, «элиминирующих» антитела. Заключение. Изучение уровня гуморального иммунитета к COVID-19 у медицинских работников имеет важное значение как с точки зрения планирования противоэпидемических мероприятий, так и прогнозирования эффективности ответа на вакцинацию к SARS-CoV-2.

Ключевые слова: гуморальный иммунитет, специфические IgG-антитела к вирусу SARS-CoV-2, специфические IgM-антитела к вирусу SARS-CoV-2, COVID-19, медицинские работники, противоэпидемические мероприятия, серопревалентность.

\section{Адрес для переписки:}

Решетникова Ирина Дмитриевна

420015, Россия, г. Казань, ул. Б. Красная, 67, ФГАОУ ВО

Казанский (Приволжский) федеральный университет.

Тел.: 8 (843) 236-67-41.

E-mail: reshira@mail.ru

\section{Для цитирования:}

Решетникова И.Д., Тюрин Ю.А., Агафонова Е.В., Куликов С.Н., Гилязутдинова Г.Ф., Лопушов Д.В., Шайхразиева Н.Д., Исаева Г.Ш., Зиатдинов В.Б. Изучение особенностей гуморального иммунного ответа к новой коронавирусной инфекции COVID-19 среди медицинских работников // Инфекция и иммунитет. 2021. Т. 11, № 5. С. 934-942. doi: 10.15789/2220-7619-SOT-1587

() Решетникова И.Д. и соавт., 2021

\author{
Contacts: \\ Irina D. Reshetnikova \\ 420015, Russian Federation, Kazan, Bolshaya Krasnaya str., 67, \\ Kazan Federal University. \\ Phone: +7 (843) 236-67-41. \\ E-mail: reshira@mail.ru
}

\section{Citation:}

Reshetnikova I.D., Tyurin Yu.A., Agafonova E.V., Kulikov S.N.,

Gilyazutdinova G.F., Lopushov D.V., Shaykhrazieva N.D., Isaeva G.Sh., Ziatdinov V.B. Study of features of humoral immune response to the new coronavirus infection COVID-19 among healthcare workers // Russian Journal of Infection and Immunity = Infektsiya i immunitet, 2021, vol. 11, no. 5, pp. 934-942. doi: 10.15789/2220-7619-SOT-1587

DOI: http://dx.doi.org/10.15789/2220-7619-SOT-1587 


\title{
STUDY OF FEATURES OF HUMORAL IMMUNE RESPONSE TO THE NEW CORONAVIRUS INFECTION COVID-19 AMONG HEALTHCARE WORKERS
}

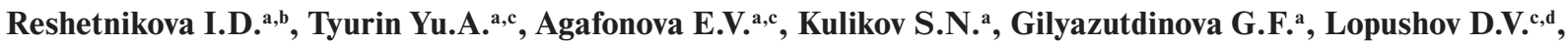 \\ Shaykhrazieva N.D. ${ }^{\text {, }}$, Isaeva G.Sh. ${ }^{\text {a,c }}$, Ziatdinov V.B. ${ }^{a}$ \\ ${ }^{a}$ Kazan Scientific Research Institute of Epidemiology and Microbiology of Rospotrebnadzor, Kazan, Russian Federation \\ ${ }^{b}$ Kazan Federal University, Kazan, Russian Federation \\ ${ }^{c}$ Kazan State Medical University, Kazan, Russian Federation \\ ${ }^{d}$ Kazan State Medical Academy, Kazan, Russian Federation
}

\begin{abstract}
Relevance. Since the beginning of the epidemic in China, there have been reports of nosocomial cases of SARS$\mathrm{CoV}-2$ infection, including among medical workers. Studies of the intensity of humoral immune response to the SARS$\mathrm{CoV}-2$ virus among medical workers who are much more likely to have professional contact with COVID-19 patients than are of particular importance. The aim is to study the seroprevalence and features of the humoral immune response to SARS-CoV-2 among medical workers. Materials and methods. The study included 61 medical workers from a multidisciplinary hospital in Kazan, which was redesigned to provide medical care to patients with new coronavirus infection, using the method of random sampling. The control group consisted of 60 non-medical workers. For the determination of IgG, a solid-phase ELISA was used. Statistical processing of the results was carried out using MS Excel software. The error of the relative value $(\mathrm{M} \pm \mathrm{m})$ was calculated, and the $95 \%$ confidence interval of the frequency of occurrence. To assess the significance of differences, the Student's test (t-test) was used for independent samples. Results. The proportion of those seropositive to SARS-CoV-2 in the study group was $45.9 \%$, compared with $21.7 \%$ in the control group. Among medical workers seropositive to the SARS-CoV-2 virus, the proportion of asymptomatic forms was $18.5 \%$, mild forms $-53.6 \%$, moderate forms and severe forms $25 \%$. Two forms of the formation of a humoral immune response among seropositive ones were revealed: the first is characterized by the gradual elimination of specific IgG antibodies to SARSCoV-2 after 8 weeks from the onset of the first symptoms of COVID-19, the second form is an increase in specific IgG to SARS-CoV-2 and a higher value of the coefficient level of IgM positivity to SARS-CoV-2 after 8-10 weeks from the onset of the first symptoms. The group of seropositive, "raising antibodies", prevailed over the group of individuals "eliminating antibodies". Among seropositive medical workers, two forms of the formation of a humoral immune response were revealed: synchronous with the parallel elimination of $\operatorname{IgG}$ and $\operatorname{IgM}$ antibodies and a parallel increase in IgG and IgM. Conclusion. The study of the level of humoral immunity to COVID-19 in medical workers is important in terms of planning both anti-epidemic measures and predicting the effectiveness of the response to vaccination to SARS-CoV-2.
\end{abstract}

Key words: humoral immunity, specific IgG and IgM antibodies to the SARS-CoV-2 virus, COVID-19, medical workers, anti-epidemic measures, seroprevalence.

В декабре 2019 г. Уханьский муниципальный комитет (КНР) по здравоохранению распространил сообщение особой важности, содержащее информацию о случаях заболевания пневмонией неизвестной этиологии, которые регистрировались в течение месяца в стационарах г. Уханя. В начале января 2020 г. в Китае наблюдался экспоненциальный рост количества больных новой инфекционной болезнью, распространившейся во все провинции Китая и за его пределы. Начался отсчет пандемии, вызванной новым коронавирусом SARS-CoV-2 [6]. С начала эпидемии в Китае появились сообщения о внутрибольничных случаях инфицирования SARS-CoV-2, в том числе и среди медицинских работников (MP) $[18,19]$. В апреле-мае 2020 г. во время эпидемии COVID-19 в Италии отмечалась подобная картина высокой заболеваемости среди МР [5]. Исследования напряженности гуморального иммунного ответа к вирусу SARS-CoV-2 среди $\mathrm{MP}$, имеющих гораздо больший риск профессионального контакта с больными COVID-19, приобретают особую важность. По данным китайских исследователей, случаи COVID-19 у MP внесли значительный вклад в заболеваемость.
В 422 медицинских учреждениях с начала эпидемии по состоянию на 11 февраля 2020 г. было выявлено 1716 лабораторно подтвержденных случаев среди МР: в Ухане - 64,0\%, в провинции Хубей $-23,3 \%$ в остальных провинциях КНР - 12,7\% [17]. Исследования, посвященные изучению особенностей гуморального иммунного ответа к SARS-CoV-2 в этой категории повышенного риска заражения, немногочисленны и противоречивы. Так, по оценкам исследователей из КНР, при обследовании 19555 МР специфические IgG к SARS-CoV-2 сохранялись только у 4\% [10]. Данные изучения напряженности иммунитета к вирусу SARS-CoV-2 среди МР одного из госпиталей в Милане (Италия) в первой половине апреля 2020 г. показали, что $\mathrm{IgG}$-антитела были выявлены у 7,4\% обследованных, а IgM - у 14,4\% [15]. Анализ 50 исследований (оценок) из 32 различных регионов мира, проводившихся в основном в локальных эпицентрах пандемии, с выборкой не менее 500 человек, по состоянию на 11 июля 2020 г. показал наличие специфических антител к SARS-CoV-2 у населения в широком диапазоне - от 0,2 до $47 \%$ [7]. 
Об уровне серопревалентности среди работников здравоохранения в Российской Федерации можно судить по первым результатам проведения масштабного проекта Роспотребнадзора по изучению популяционного иммунитета к вирусу SARS-CoV-2: так, в Санкт-Петербурге данный показатель составил 27,1\% [4], а в Ленинградской области он оказался равным $18,1 \%[3]$.

Таким образом, актуальным является вопрос о сроках возникновения, напряженности и продолжительности сохранения специфических антител к вирусу SARS-CoV-2 у MP. Решение этого вопроса необходимо для выявления частоты распространения инфекции среди контингентов с высоким риском заражения в учреждениях здравоохранения, установления числа бессимптомных форм болезни, ретроспективного анализа популяционного иммунитета. В связи с активно идущими разработками вакцинных препаратов и началом массовой вакцинации от COVID-19, актуальной задачей, требующей решения, являются исследования, показывающие, будут ли вакцины эффективно индуцировать выработку антител и насколько долго антитела будут защищать от повторных заражений.

Цель исследования - изучить серопревалентность и особенности гуморального иммунного ответа на вирус SARS-CoV-2 среди MP.

\section{Материалы и методы}

Методом случайной выборки в исследование включили 61 МР из многопрофильного стационара г. Казани, который был перепрофилирован для оказания медицинской помощи больным коронавирусной инфекцией. После подписания информированного согласия были собраны клинические, анамнестические данные и эпидемиологический анамнез в отношении COVID-19 с помощью специально разработанной анкеты. Антитела IgG- и IgM-классов были исследованы в динамике дважды с интервалом в 30 дней (30.06.2020 и 27.07.2020) у МР с отсутствием и наличием признаков ОРВИ (трахеит, бронхит, фарингит) в анамнезе в течение предшествующих трех месяцев.

В качестве группы сравнения методом случайной выборки была сформирована группа лиц из 60 немедицинских работников (не-МР), у которых были исследованы сыворотки крови на антитела IgG и $\operatorname{IgM~в~динамике~заболе-~}$ вания дважды с тем же интервалом и в тот же период, что и у МР. Исследование было одобрено локальным этическим комитетом ФБУН КНИИЭМ Роспотребнадзора.

Определение IgG-антител к SARS-CoV-2 проводилось методом ИФА с использованием отечественных диагностических тест-систем с сорбированным в лунках планшета рекомбинантным полноразмерным тримеризованным гликопротеином (Spike-белок) вируса SARSCoV-2 («SARS-CoV-2-IgG-ИФА-БЕСТ», АО «Вектор-Бест», Россия).

Для детекции IgM-антител к SARS-CoV-2 использовали отечественные тест-системы, основанные на непрямом варианте твердофазного ИФА с иммобилизованными в лунках антителами к IgM человека и выявлением специфических антител с помощью конъюгатов, содержащих антигены вируса - N-белок нуклеокапсида («SARS-CoV-2-IgM-ИФА-БЕСТ», АO «Вектор-Бест», Россия) [2].

Результаты исследований выражались в виде коэффициента позитивности (КП), представляющего собой отношение оптической плотности образца к критической оптической плотности, высчитываемой в каждом анализе. Интерпретация результатов была следующей: в зависимости от использованной тест-системы положительными считались образцы с КП, превышающим 1,1-1,2; отрицательными с КП менее $0,8-0,9$.

Промежуточные значения КП свидетельствовали о сомнительном или неопределенном результате («серая зона»).

Пациентам основной и контрольной групп было проведено определение PHK вируса SARS$\mathrm{CoV}-2$ в мазках из носоглотки методом ПЦР с помощью зарегистрированного набора реагентов «РеалБест PHK SARS-CoV-2» (AO «ВекторБест», Россия).

Статистическая обработка результатов проводилась с применением программного обеспечения MS Excel. Рассчитана ошибка относительной величины $(\mathrm{M} \pm \mathrm{m})$ и 95\% доверительный интервал частоты встречаемости. Для оценки достоверности различий применяли критерий Стьюдента (t-критерий) для независимых выборок. Различия считали достоверными при р $<0,05 \%$.

\section{Результаты и обсуждение}

Средний возраст обследуемых МР составил $40,1 \pm 0,2$ лет, из них врачей -37 (60,7\%), среднего медицинского персонала - 21 (34,4\%), вспомогательного персонала - 3 (4,9\%). Средний возраст в группе сравнения (не-МР) составил $48,0 \pm 0,7$ лет. При изучении гуморального иммунного ответа к вирусу SARS-CoV-2 количество серопозитивных MP составило 28 (45,9\%), а серонегативных - $33(54,1 \%)$. В группе сравнения (не-МР) количество серопозитивных составило $13(21,7 \%)$, а серонегативных - 47 (78,3\%). Таким образом, доля серопозитивных к SARS-CoV-2 не-MP была в 2 раза ниже, чем в основной группе $(\mathrm{z}=2,8 ; \mathrm{p}<0,05)$. 
В группе серонегативных MP у 2 (3,3\%) человек специфические антитела к вирусу SARS$\mathrm{CoV}-2$ не определялись, но в анамнезе были выявлены перенесенные ранее специфические симптомы легкой формы вирусной инфекции, у одного из них был получен положительный результат ПЦР SARS-CoV-2. В группе не-MP среди серонегативных лиц у 6 человек $(10,0 \%)$ были получены положительные результат ПЦР теста к SARS-CoV-2.

В группе из 28 (45,9\%) серопозитивных MP не выявлено в анамнезе признаков острой респираторной вирусной инфекции у $6(8,5 \%)$ человек. У $22(36,0 \%)$ МР в анамнезе в течение последних 3 месяцев отмечались различные симптомы острого респираторного заболевания, включающие проявления поражения верхних дыхательных путей, пищеварительного тракта, явления интоксикации и повышение температуры тела (табл. 1). У более половины из них регистрировались субфебрилитет, кашель. В 39,0\% случаев выявлено чувство заложенности в грудной клетке. У каждого третьего - потеря обоняния и вкуса, одышка. У каждого десятого регистрировалась симптоматика поражения ЖКТ (диарея, тошнота). У каждого третьего МР длительно сохранялся астено-невротический синдром.
Клинические проявления легкой степени тяжести вирусной инфекции выявлены у 15 (53,6\%) человек, средней степени тяжести - у 7 (25,0\%). У $9(32,1 \%)$ обследованных течение вирусной инфекции осложнилось развитием пневмонии с картиной поражения легких КТ-1 у 5 человек; КТ-2 - у 2 человек, КТ-3 и КТ-4 - у 1 человека.

У 3 серопозитивных лиц в группе сравнения выявлены симптомы астено-невротического синдрома $(5,0 \%)$, у 2 (3,3\%) человек отмечался сухой кашель и повышение температуры до субфебрильных значений. В остальных $8(13,3 \%)$ случаях клинических симптомов острого респираторного вирусного заболевания не регистрировалось, при этом в трех из них были получены положительные результаты ПЦР теста к SARS-CoV-2.

Хронические сопутствующие заболевания в анамнезе выявлены у 6 обследуемых МР $(21,4 \%)$, из них по 2 случая гипотиреоза и хронического тонзиллита, по одному случаю хронического фарингита и бронхиальной астмы. Среди данного контингента обследуемых не было курящих. Каждый третий МР в течение предыдущего года был вакцинирован от гриппа.

Гуморальный иммунный ответ на вирус SARS-CoV-2 у 28 серопозитивных MP был неоднородным. Было выделено 10 МР, у которых

Таблица 1. Основные симптомы перенесенной острой респираторной вирусной инфекции у серопозитивных к SARS-CoV-2 медицинских работников $(n=28)$ и серопозитивных лиц $(n=13)$ группы сравнения

Table 1. The main symptoms of an acute respiratory viral infection in SARS-CoV-2 seropositive medical workers $(n=28)$ and comparison group of seropositive persons $(n=13)$

\begin{tabular}{|c|c|c|c|}
\hline $\begin{array}{l}\text { Симптомы } \\
\text { Symptoms }\end{array}$ & $\begin{array}{c}\text { Частота встречаемости } \\
\text { в абс.ч., \% [95\% ДИ] (МР) } \\
\text { Frequency of occurrence, abs., } \\
\% \text { [95\% Cl] (medical workers) }\end{array}$ & $\begin{array}{c}\text { Частота встречаемости } \\
\text { в абс.ч., \% [95\% ди] } \\
\text { (группа сравнения) } \\
\text { Frequency of occurrence, abs., } \\
\% \text { [95\% Cl] (comparison group) }\end{array}$ & $\mathbf{P}$ \\
\hline $\begin{array}{l}\text { Повышение температуры } \\
\text { Temperature increase }\end{array}$ & $\begin{array}{c}15 \\
53,6[34,2-72,0]\end{array}$ & $\begin{array}{c}2 \\
15,4[2,7-46,3]\end{array}$ & $<0,05$ \\
\hline $\begin{array}{l}\text { Кашель } \\
\text { Cough }\end{array}$ & $\begin{array}{c}14 \\
50,0[31,0-69,0]\end{array}$ & $\begin{array}{c}2 \\
15,4[2,7-46,3]\end{array}$ & $<0,05$ \\
\hline $\begin{array}{l}\text { Одышка } \\
\text { Dyspnea }\end{array}$ & $\begin{array}{c}9 \\
32,1[16,6-52,4]\end{array}$ & - & - \\
\hline $\begin{array}{l}\text { Ощущение заложенности в грудной клетке } \\
\text { Feeling of congestion in the chest }\end{array}$ & $\begin{array}{c}11 \\
39,2[22,1-59,3]\end{array}$ & - & - \\
\hline $\begin{array}{l}\text { Потеря обоняния и вкуса } \\
\text { Loss of smell and taste }\end{array}$ & $\begin{array}{c}9 \\
32,1[18,0-51,0]\end{array}$ & - & - \\
\hline $\begin{array}{l}\text { Тошнота, рвота } \\
\text { Nausea, vomiting }\end{array}$ & $\begin{array}{c}3 \\
10,7[3,7-27,2]\end{array}$ & - & - \\
\hline $\begin{array}{l}\text { Диарея } \\
\text { Diarrhea }\end{array}$ & $\begin{array}{c}3 \\
10,7[3,7-27,2]\end{array}$ & - & - \\
\hline $\begin{array}{l}\text { Астено-невротический синдром } \\
\text { Astheno-neurotic syndrome }\end{array}$ & $\begin{array}{c}9 \\
32,1[18,0-51,0]\end{array}$ & $\begin{array}{c}3 \\
23,1[6,2-54,0]\end{array}$ & $>0,05$ \\
\hline $\begin{array}{l}\text { Пневмония } \\
\text { Pneumonia }\end{array}$ & $\begin{array}{c}9 \\
32,1[18,0-51,0]\end{array}$ & - & - \\
\hline $\begin{array}{l}\text { Bcero серопозитивных } \\
\text { Total }\end{array}$ & $\begin{array}{c}28 \\
100 \%\end{array}$ & $\begin{array}{c}13 \\
100 \%\end{array}$ & $<0 / 0$ \\
\hline
\end{tabular}


выявлено снижение уровня специфических IgG к SARS-CoV-2, зарегистрированное через 30 дней от первого исследования крови («группа элиминирующих антитела»), и 18 МР, у которых наблюдалось увеличение уровня специфических IgG-антител к SARS-CoV-2 («повышающие антитела»), при этом в группе сравнения (неМР) у всех обследованных через 30 дней регистрировалось снижение КП уровня IgG и IgM к SARS-CoV-2. При оценке возрастного фактора у MP с разным характером гуморального иммунного ответа достоверных различий по возрасту не выявлено.

Показатели гуморального иммунного ответа к вирусу SARS-CoV-2 у 28 серопозитивных MP в группе «элиминирующих» и «повышающих» антитела, а также в группе сравнения представлены в табл. 2.

При анализе полученных данных установлено, что в группе «элиминирующих» антитела МР на первом этапе серологического исследования показатель КП IgG к вирусу SARS-CoV-2 был в 3,5 раза выше, чем в группе «повышающих» антитела МР (табл. 2). Для КП IgM была выявлена обратная закономерность: в группе «элиминирующих» антитела этот показатель был ниже практически в 2 раза, чем в группе «повышающих» антитела».

На втором этапе серологического исследования происходило снижение $\mathrm{K}$ П IgG к вирусу SARS-CoV-2 в группе «элиминирующих» антитела на 5,1 единицы, а в группе «повышающих» антитела отмечен рост показателя КП IgG к виpycy SARS-CoV-2 на 13,3 единицы. Учитывая разнонаправленный характер изменения уровня специфических антител IgG к вирусу SARSCoV-2 в двух группах MP, представлялось интересным проанализировать на каких сроках до первой точки серологического исследования наблюдались клинические проявления ОРВИ, если таковые имелись.
Установлено, что в группе «элиминирующих» антитела от начала первых симптомов до первой точки серологического исследования (30.06.2020) прошло в среднем 58,8土6,4 (Me = 63) дня, а в группе «повышающих» антитела $44,7 \pm 5,2(\mathrm{Me}=40)$ дней (различия в сроках достоверны, $\mathrm{p}<0,05)$. Соответственно, в первой группе МР от начала первых симптомов до второго серологического исследования (27.07.2020) прошло в среднем 88,8 $\pm 7,4$ ( $\mathrm{Me}=93)$ дня, а во второй группе - 74,8土5,0 (Me = 70) (различия достоверны).

Таким образом, можно выделить два варианта гуморального иммунного ответа у МР: первый характеризовался постепенной элиминацией специфических IgG антител к SARS-CoV-2 после 8 недели от появления первых симптомов ОРВИ, второй - нарастанием специфических IgG к SARS-CoV-2 и более высоким значением уровня КП IgM SARS-CoV-2 после 8-10 недели от появления первых симптомов (рис.).

По данным нашего исследования, у 61 МР одного из перепрофилированных госпиталей для оказания медицинской помощи больным COVID-19 г. Казани выявлена выраженная серопревалентность к SARS-CoV-2, составившая 45,9\%.

Среди серопозитивных к вирусу SARS-CoV-2 $\mathrm{MP}$ доля лиц с бессимптомными формами COVID-19 составила 6 (18,5\%), легкими формами - 15 (53,6\%), среднетяжелыми и тяжелыми формами - 7 (25\%). Исследования, проведенные в нашей стране и за рубежом, показывают, что вирус SARS-CoV-2 может вызвать различные варианты гуморального ответа: у части лиц, имеющих высокую восприимчивость, как правило, развивается манифестная инфекция, у части заболевание протекает бессимптомно и завершается только формированием адаптивного иммунитета (инаппарантная сероконверсия) и, наконец, у наиболее резистентных лиц заболевание заканчивается носительством, не оставляющим гумо-

\section{Таблица 2. Показатели гуморального иммунного ответа к вирусу SARS-CoV-2 у серопозитивных MP}

Table 2. Indicators of humoral immune response to the SARS-CoV-2 virus in seropositive medical workers

\begin{tabular}{|c|c|c|c|}
\hline \multirow{2}{*}{$\begin{array}{c}\text { Наименование группы } \\
\text { серопозитивных MP } \\
\text { Name of the group of seropositive } \\
\text { medical workers }\end{array}$} & \multirow{2}{*}{$\begin{array}{c}\text { Дата } \\
\text { исследования } \\
\text { Date }\end{array}$} & \multicolumn{2}{|c|}{$\begin{array}{c}\text { Показатели уровня антител к вирусу SARS-CoV-2 } \\
\text { Indicators of the level of antibodies to the SARS-CoV-2 virus }\end{array}$} \\
\hline & & $\begin{array}{c}\lg G(K \Pi) \\
\lg G(C P)\end{array}$ & $\begin{array}{l}\lg M(K \Pi) \\
\lg M(C P)\end{array}$ \\
\hline \multirow{2}{*}{$\begin{array}{l}\text { «Элиминирующие» антитела, } \mathbf{n}=10 \\
\text { «Eliminating» antibodies, } \mathrm{n}=10\end{array}$} & 30.06 .2020 & $15,9 \pm 1,6^{\star}$ & $0,7 \pm 0,15^{\#}$ \\
\hline & 27.07 .2020 & $10,8 \pm 1,5^{\star}$ & $\mathrm{H} / \mathrm{O}$ \\
\hline \multirow{2}{*}{$\begin{array}{l}\text { «Повышающие» антитела, } \mathbf{n = 1 8} \\
\text { «Raising» antibodies, } n=18\end{array}$} & 30.06 .2020 & $4,5 \pm 1,7^{\star \star}$ & $1,2 \pm 0,7$ \\
\hline & 27.07 .2020 & $17,8 \pm 1,0^{\star \star}$ & $2,1 \pm 0,7^{\#}$ \\
\hline \multirow{2}{*}{$\begin{array}{l}\text { Группа сравнения, } \mathbf{n = 1 3} \\
\text { Comparison group, } n=13\end{array}$} & 30.06 .2020 & $11,76 \pm 1,8^{*}$ & $4,4 \pm 1,8$ \\
\hline & 27.07 .2020 & $9,6 \pm 1,3^{\star}$ & $1,3 \pm 0,2^{\#}$ \\
\hline
\end{tabular}

Примечание. * - значения достоверно различаются внутри группы, p <0,05; ** - значения достоверно различаются внутри группы, р < 0,04; \# - значения достоверно различаются между группами, $\mathrm{p}<0,05 ;$ КП - коэффициент позитивности.

Note. * - values significantly differ within the group, $p<0.05 ;{ }^{* \star}-$ values significantly differ within the group, $p<0.04 ;{ }^{*}-$ values significantly differ between groups, $\mathrm{p}<0.05 ; \mathrm{CP}-$ coefficient of positivity. 
рального иммунного ответа [4, 9]. SARS-CoV-2 относится к большой группе коронавирусов, среди которых встречаются низкопатогенные представители, вызывающие сезонные ОРВИ, способные формировать перекрестный иммунитет [14]. В связи с этим представляло интерес оценить наличие серопревалентности у МР, перенесших ОРВИ неуточненной этиологии.

В нашем исследовании из 61 обследованного MP у 25 (40,9\%) отмечались в анамнезе клинические проявления ОРВИ в течение предшествующих 3 месяцев до первого серологического обследования. У 22 из них выявлены антитела к SARS-CoV-2 (36,1\%). Поскольку детальной расшифровки возбудителей ОРВИ не проводилось, нельзя исключать, что у части из них серопревалентность могла быть обусловлена перекрестным иммунитетом к другим представителям $\beta$-коронавирусов человека $(\beta \mathrm{HCoV})[9]$.

Распространенность бессимптомных форм среди серопозитивных лиц в популяционном исследовании, проведенном в РФ по инициативе Роспотребнадзора, изучали по выявлению доли лиц, у которых отсутствует хотя бы один признак: диагноз «COVID-19», либо положительная ПЦР, либо признаки ОРВИ [3, 4]. В нашем исследовании у 6 МР выявленные антитела к SARS-CoV-2 явились случайной находкой при отсутствии в анамнезе явлений ОРВИ в предшествующие 3 месяца $(9,8 \%)$. Значительная доля бессимптомных форм инфекции COVID-19 характеризует высокую интенсивность эпидемического процесса. Полученные результаты необходимо учитывать при организации профилактических мероприятий, а также прогнозировании эффективности ответа на вакцинацию к SARS-CoV-2.

Одной из важных задач было изучение связи между серопревалентностью и результатами определения PHK SARS-CoV-2 в полимеразной цепной реакции (ПЦР). В нашем исследовании у 18 из 61 МР был получен позитивный результат ПЦР-тестирования $(29,5 \%)$, что сопровождалось развитием гуморального адаптивного иммунного ответа к SARS-CoV-2 в 16 случаях (88,9\%), 2 ПЦР-позитивных МР были серонегативными $(11,1 \%)$. Согласно результатам, полученным Hou Н. и соавт. (2020), выработка IgG к SARS-CoV-2 наблюдалась как у лиц с выраженными симптомами заболевания, так и у лиц без симптомов [7]. На ранней стадии выздоровления антитела переставали обнаруживаться у 12,0\% пациентов с выраженными симптомами заболевания, а у лиц, перенесших инфекцию бессимптомно, антитела переставали обнаруживаться в 40,0\% случаев [13]. Согласно сообщению Kellam P. и соавт. (2020), специфические IgG к SARS-CoV-2 начинают вырабатываться примерно через 3-4 недели после заражения и через 1-2 недели после появления симптомов заболевания [9]. Результаты другого исследования показывают, что после перенесенного заболевания COVID-19, подтвержденного с помощью ПЦР-анализа, у $18 \%$ лиц антитела к вирусу SARS-CoV-2 не выявляются [3]. Особенностью COVID-19 является значитель-
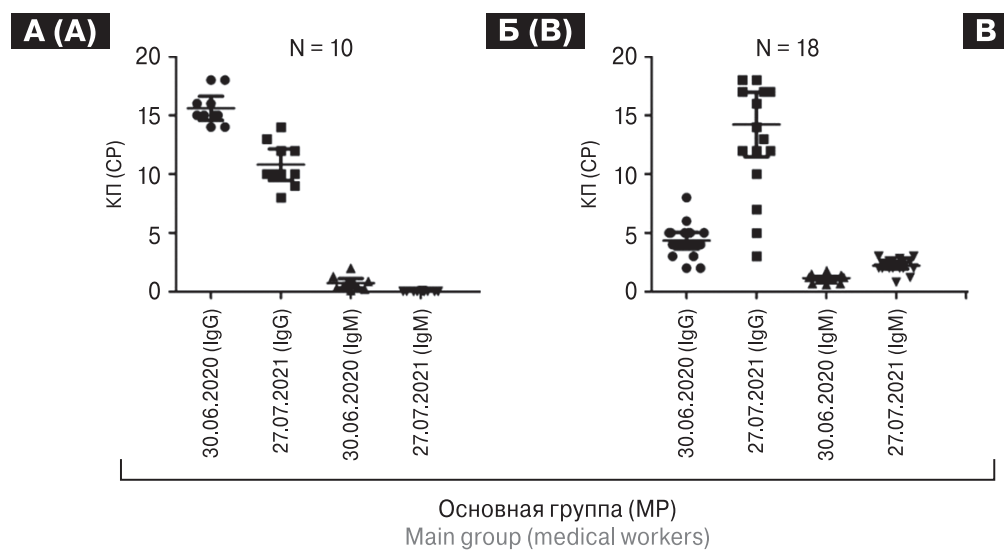

B (C)

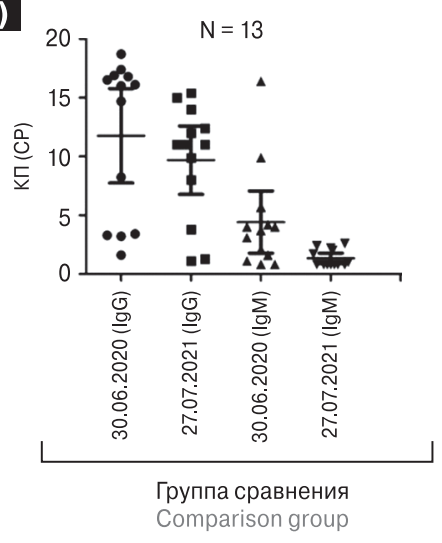

\section{Рисунок. Динамика антител к вирусу SARS-CoV-2 в двух группах серопозитивных лиц: основная группа (MP) и группа сравнения}

Figure. Dynamics of antibodies to the SARS-CoV-2 virus in two groups of seropositive individuals: the main group (medical workers) and the comparison group

Примечание. А) серопозитивные МР, показана динамика уровня антител по КП по типу «элиминирующие»; Б) серопозитивные МР, показана динамика уровня антител по КП по типу «повышающие»; В) показана динамика уровня антител по КП у серопозитивных лиц группы сравнения.

Note. A) seropositive medical workers group shows the dynamics of level of antibodies to the CP type «Eliminating»; B) seropositive medical workers group shows the dynamics of level of antibodies to the CP type «Increasing»; C) shows the dynamics of level of antibodies to the $\mathrm{CP}$ in seropositive individuals of the comparison group. 
ная гетерогенность гуморального ответа как в процессе заболевания, так и в период реконвалесценции, причем не всегда можно установить связь между серопозитивностью переболевшего и тяжестью перенесенного заболевания [3, 4, 12]. Длительность сохранения антител против SARS-CoV-2 изучена недостаточно, при этом известно, что продолжительность иммунитета к родственным коронавирусам MERS-CoV и SARS-CoV может сохраняться до 3 лет [2].

В нашем исследовании выявлено две формы формирования гуморального иммунного ответа: синхронная с параллельной элиминацией IgG- и IgM-антител и синхронная с параллельным увеличением $\operatorname{IgG}$ и $\operatorname{IgM}$. Китайские исследователи, анализируя гуморальный ответ 27 больных COVID-19 в течение 20 дней, выделяют несколько вариантов формирования серопозитивности у таких пациентов: синхронная серопозитивность - одновременное выявление IgG и IgM (10 случаев); IgM выявляется раньше, чем IgG (7 случаев); IgM выявляется позже, чем IgG (10 случаев) [19]. Сохранение IgG-антител более 7-8 недель с параллельно идущим процессом элиминации IgM у 76 реконвалесцентов c COVID-19 описывает группа ученых из ФБУН МНИИЭМ им. Габричевского. Отмечено также, что у двух из 76 обследованных больных COVID-19 антитела не вырабатывались [2]. В ходе нашего исследования выявлена синхронная серопозитивность с одновременным выявлением IgG и IgM. Четко прослеживается формирование двух групп - «увеличивающих антитела» и «элиминирующих антитела» в сроки от 6-7 недель от начала симптомов ОРВИ в анамнезе с сохранением данных разнонаправленных тенденций в динамике вплоть до 1112 недели наблюдения. По данным разных авторов, специфические IgG к SARS-CoV-2 начинают вырабатываться примерно через 3-4 недели после заражения и через 1-2 недели после появления симптомов заболевания [11].

Длительность сохранения антител против SARS-CoV-2 изучена недостаточно, что требует длительного динамического наблюдения за когортой серопозитивных лиц.

По результатам нашего исследования, ${ }^{2} /{ }_{3}$ МР имели адекватный гуморальный иммунологический ответ к S-белку (Spike-белок, рецепторный белок (гликопротеин), находящийся в су- перкапсидной оболочке и образующий так называемые «шипы» вируса SARS-CoV-2). Данная группа серопозитивных MP, «повышающих» антитела, характеризовалась более высокой выработкой протективных антител к SARS-CoV-2.

Возможность обнаружения IgG-антител к S-белку имеет большое значение, учитывая данные литературы о том, что именно эти антитела обеспечивают защиту при инфицировании SARS-CoV-2 путем нейтрализации вируса $[1,18]$, a сам S-белок рассматривается как кандидат при конструировании вакцин против COVID-19 [19]. Проведенные нами исследования позволяют наметить новые диагностические подходы и определить группы МР с различным типом гуморального иммунного ответа, у которых можно прогнозировать иммунный ответ на предстоящую вакцинацию от SARS-CoV-2.

\section{Выводы}

При обследовании 61 МР многопрофильного стационара г. Казани, который был перепрофилирован для оказания медицинской помощи больным коронавирусной инфекцией, выявлена выраженная серопревалентность к SARSCoV-2, составившая 45,9\%, что достоверно превышает в 2 раза уровень в обычной выборке неМР сопоставимого возраста.

Среди серопозитивных MP к вирусу SARS$\mathrm{CoV}-2$ доля лиц с бессимптомными формами составила $18,5 \%$, с легкими формами - 53,6\%, среднетяжелыми и тяжелыи формами - 25\%, а среди серопозитивных лиц группы сравнения (не-МР) у $38,5 \%$ регистрировалась легкая форма заболевания, у 61,5\% - бессимптомная.

Среди серопозитивных МР выявлено два варианта формирования гуморального иммунного ответа: синхронный с параллельной элиминацией IgG- и IgM-антител и синхронный с параллельным увеличением IgG и IgM.

В группе серопозизитивных МР количество лиц, «Повышающих» антитела, превалировало над количеством лиц, «элиминирующих» антитела.

Изучение уровня гуморального иммунитета к COVID-19 у MP имеет важное значение с точки зрения как планирования противоэпидемических мероприятий, так и прогнозирования эффективности ответа на вакцинацию K SARS-CoV-2.

\section{Список литературы/References}

1. Кутырев В.В., Попова А.Ю., Смоленский В.Ю., Ежлова Е.Б., Демина Ю.В., Сафронов В.А., Карнаухов И.Г., Иванова А.В., Щербакова С.А. Эпидемиологические особенности новой коронавирусной инфекции (COVID-19). Cообщение 1: Модели реализации профилактических и противоэпидемических мероприятий // Проблемы особо опасных инфекций. 2020. № 1. С. 6-13. [Kutyrev V.V., Popova A.Yu., Smolensky V.Yu., Ezhlova E.B., Demina Yu.V., Safronov V.A., Karnaukhov I.G., Ivanova A.V., Shcherbakova S.A. Epidemiological features of new coronavirus infection (COVID-19). Communication 1: Modes of implementation of preventive and anti-epidemic measures. Problemy osobo opasnykh infektsiy $=$ Problems of Particularly Dangerous Infections, 2020, no. 1, pp. 6-13. (In Russ.)] doi: 10.21055/0370-1069-2020-1-6-13 
2. Новикова Л.И., Бочкарева С.С., Алешкин А.В., Комбарова С.Ю., Карпов О.Э., Пулин А.А., Орлова О.А., Лебедин Ю.С., Воробьев А.М., Мехтиев Э.Р. Динамика антител к различным антигенам коронавируса SARS-CoV-2 у больных с подтвержденной инфекцией COVID-19 // Молекулярная диагностика и биобезопасность - 2020. Всеросс. науч.-практ. конф. с междунар. участием (6-8 октября 2020 года): сб. материалов. Под ред. В.Г. Акимкина, М.Г. Твороговой. М.: ФБУН ЦНИИ эпидемиологии Роспотребнадзора, 2020. C. 159-164. [Novikova L.I., Bochkareva S.S., Aleshkin A.V., Kombarova S.Iu., Karpov O.E., Pulin A.A., Orlova O.A., Lebedin Iu.S., Vorobev A.M., Mekhtiev E.R. Dynamics of antibodies to various antigens of the SARS-CoV-2 coronavirus in patients with confirmed COVID-19 infection. In: Molecular Diagnostics and Biosafety - 2020. Russian national scientific and practical conference with international participation (October, 6-8, 2020): Conference proceedings. Eds. Akimkin V.G., Tvorogova M.G. Moscow: Central Research Institute for Epidemiology, 2020, pp. 159-164. (In Russ.)] doi: 10.36233/978-5-9900432-9-9-159

3. Попова А.Ю., Ежлова Е.Б., Мельникова А.А., Историк О.А., Мосевич О.С., Лялина Л.В., Смирнов В.С., Черный М.А., Балабышева Н.С., Логинова И.С., Владимирова О.С., Самоглядова И.С., Васев Н.А., Румянцева С.В., Чупалова Е.Ю., Селиванова Г.В., Муравьева М.В., Тимофеева Л.В., Ханкишиева Э.Н., Тыльчевская В.Д., Никитенко Н.Д., Костеницкая Т.И., Виркунен Н.В., Климкина И.М., Кузьмина Т.М., Дегтяренко Н.В., Базунова А.И., Филиппова Л.А., Пальчикова Н.А., Кукушкин А.В., Арсентьева Н.А., Бацунов О.К., Богумильчик Е.А., Воскресенская Е.А., Дробышевская В.Г., Зуева Е.В., Кокорина Г.И., Курова Н.Н., Любимова Н.Е., Ферман Р.С., Хамдулаева Г.Н., Хамитова И.В., Хорькова Е.В., Миличкина А.М., Дедков В.Г., Тотолян А.А. Оценка популяционого иммунитета к SARS-CoV-2 среди населения Ленинградской области в период эпидемии COVID-19 // Проблемы особо опасных инфекций. 2020. № 3. C. 114-123. [Popova A.Yu., Ezhlova E.B., Mel'nikova A.A., Istorik O.A., Mosevich O.S., Lyalina L.V., Smirnov V.S., Cherny M.A., Balabysheva N.S., Loginova I.S., Vladimirova O.S., Samoglyadova I.S., Vasev N.A., Rumyantseva S.V., Chupalova E.Yu., Selivanova G.V., Murav'eva M.V., Timofeeva L.V., Khankishieva E.N., Tyl'chevskaya V.D., Nikitenko N.D., Kostenickaya T.I., Virkunen N.V., Klimkina I.M., Kuz'mina T.M., Degtyarenko N.V., Bazunova A.I., Filippova L.A., Pal'chikova N.A., Kukshkin A.V., Arsent'eva N.A., Batsunov O.K., Bogumil'chik E.A., Voskresenskaya E.A., Drobyshevskaya V.G., Zueva E.V., Kokorina G.I., Kurova N.N., Lyubimova N.E., Ferman R.S., Hamdulaeva G.N., Khamitova I.V., Khor'kova E.V., Milichkina A.M., Dedkov V.G., Totolian A.A. Assessing herd immunity of Leningrad Region population during COVID-19 epidemic. Problemy osobo opasnykh infektsiy $=$ Problems of Particularly Dangerous Infections, 2020, no. 3, pp. 114-123. (In Russ.)] doi: 10.21055/0370-1069-2020-3-114-123

4. Попова А.Ю., Ежлова Е.Б., Мельникова А.А., Башкетова Н.С., Фридман Р.К., Лялина Л.В., Смирнов В.С., Чхинджерия И.Г., Гречанинова Т.А., Агапов К.А., Арсентьева Н.А., Баженова Н.А., Бацунов О.К., Данилова Е.М., Зуева Е.В., Комкова Д.В., Кузнецова Р.Н., Любимова Н.Е., Маркова А.Н., Хамитова И.В., Ветров В.В., Миличкина А.М., Дедков В.Г., Тотолян А.А. Популяционный иммунитет к вирусу SARS-CoV-2 среди населения Санкт-Петербурга в активную фазу эпидемии COVID-19 // Проблемы особо опасных инфекций. 2020. № 3. C. 124-130. [Popova A.Yu., Ezhlova E.B., Mel'nikova A.A, Bashketova N.S., Fridman R.K., Lyalina L.V., Smirnov V.S., Chkhindzheriya I.G., Grechaninova T.A., Agapov K.A., Arsent'eva N.A., Bazhenova N.A., Batsunov O.K., Danilova E.M., Zueva E.V., Komkova D.V., Kuznetsova R.N., Lyubimova N.E., Markova A.N., Khamitova I.V., Milichkina A.M., Dedkov V.G., Totolian A.A. Herd immunity of St. Petersburg population during the active phase of COVID-19 epidemic. Problemy osobo opasnykh infektsiy $=$ Problems of Particularly Dangerous Infections, 2020, no. 3, pp. 124-130. (In Russ.)] doi: 10.21055/0370-1069-2020-3-124-130

5. Семенов A.В., Пшеничная Н.Ю. Уроки эпидемии COVID-19 в Италии // Инфекция и иммунитет. 2020. T. 10, № 3. C. 410-420. [Semenov A.V., Pshenichnaya N.Yu. Lessons to learn: COVID-19 epidemic in Italy. Infektsiya i immunitet $=$ Russian Journal of Infection and Immunity, 2020, vol. 10, no. 3, pp. 410-420. (In Russ.)] doi: 10.15789/2220-7619-LTL-1468

6. Chan J.F.W., Yuan S., Kok K.H., To K.K.W., Chu H., Yang J., Tsoi H.W., Lo S.K., Chan K.H., Poon V.K., Chan W.M., Ip J.D., Cai J.P., Cheng V.C., Chen H., Hui C.K., Yuen K.Y. A familial of pneumonia associated with the 2019 novel coronavirus indicating person-to-person transmission: a study of a family cluster. Lancet, 2020, vol. 395, no. 10223, pp. 514-523. doi: 10.1016/ S0140-6736(20)30154-9

7. Hou H., Wang T., Zhang B., Luo Y., Mao L., Wang F., Wu S., Sun Z. Detection of IgM and IgG antibodies in patients with coronavirus disease 2019. Clin. Transl. Immunology, 2020, vol. 9, no 5: e01136. doi: 10.1002/cti2.1136

8. Ioannidis J., Long Q.X., Liu B.Z., Deng H.J., Wu G.C., Deng K., Chen Y.K. The infection fatality rate of COVID-19 inferred from seroprevalence data. Nat. Med., 2020, vol. 29. doi: 10.1101/2020.05.13.20101253

9. Kellam P., Barclay W. The dynamics of humoral immune responses following SARS-CoV-2 infection and the potential for reinfection. J. Gen. Virol., 2020, vol. 101, no. 8, pp. 791-797. doi: 10.1099/jgv.0.001439

10. Liu T., Wu S., Tao H., Zeng G., Zhou F., Guo F., Wang X. Prevalence of IgG antibodies to SARS-CoV-2 in Wuhan - implications for the ability to produce long-lasting protective antibodies against. SARS-CoV-2. medRxiv, 2020: 20130252. doi: 10.1101/ 2020.06.13.20130252

11. Long Q.-X., Deng H.-J., Chen J., Hu J., Liu B.-Zh., Liao P., Lin Y., Yu L.-H., Mo Zh., Xu Y.-Y., Gong F., Wu G., Zhang X.-Z., Chen Y.-K., Li Zh.-J., Wang K., Zhang X.-L., Tian W.-G.,Niu Ch.-Ch., Yang Q.-J., Xiang J.-L., Du H.-X., Liu H.-W., Lang Ch., Luo X.-H., Wu Sh.-B., Cui X.-P., Zhou Zh., Wang J., Xue Ch.-J., Li X.-F., Wang L., Tang X.-J., Zhang Y., Qiu J.-F., Liu X.-M., Li J.-J., Zhang D.-Ch., Zhang F., Cai X.-F., Wang D., Hu Y., Ren J.-H., Tang N., Liu P., Li Q., Huang A.-L. Antibody responses to SARS-CoV-2 in COVID-19 patients: the perspective application of serological tests in clinical practice. medRxiv, 2020: 20038018. doi: 10.1101/2020.03.18.20038018

12. Ng K.W., Faulkner N., Cornish G.H., Rosa A., Harvey R., Hussain S., Ulferts R., Earl C., Wrobel A.G., Benton D.J., Roustan C., Bolland W., Thompson R., Agua-Doce A., Hobson P., Heaney J., Rickman H., Paraskevopoulou S., Houlihan C.F., Thomson K., Sanchez E., Shin G.Y., Spyer M.J., Joshi D., O’Reilly N., Walker P.A., Kjaer S., Riddell A., Moore C., Jebson B.R., Wilkinson M., Marshall L.R., Rosser E.C., Radziszewska A., Peckham H., Ciurtin C., Wedderburn L.R., Beale R., Swanton C., Gandhi S., Stockinger B., McCauley J., Gamblin S.J., McCoy L.E., Cherepanov P., Nastouli E., Kassiotis G. Pre-existing and de novo humoral immunity to SARS-CoV-2 in humans. bioRxiv, 2020, vol. 370, no. 6522, pp. 1339-1343. doi: 10.1126/science.abe1107

13. Paudel S., Dangal G., Chalise A., Bhandari T.R., Dangal O. The Coronavirus pandemic: what does the evidence show? J. Nepal Health Res. Counc., 2020, vol. 18, no. 1, 9 p. doi: 10.33314/jnhrc.v18i1.2596 
14. Sethuraman N., Jeremiah S.S., Ryo A. Interpreting diagnostic tests for SARS-CoV-2. JAMA, 2020, vol. 323, no. 22, pp. 22492251. doi: 10.1001/jama.2020.8259

15. Sotgiu G., Barassi A., Miozzo M., Saderi L., Piana A., Orfeo N., Colosio C., Felisati G., Davì M., Gerli G.A., Centanni S. SARSCoV-2 specific serological pattern in healthcare workers of an Italian COVID-19 forefront hospital. BMC Pulm. Med., 2020, vol. 20, no. 1: 203. doi: 10.1186/s12890-020-01237-0

16. Spina S., Marrazzo F., Migliari M., Stucchi R., Sforza A., Fumagalli R. The response of Milan's Emergency Medical System to the COVID-19 outbreak in Italy. Lancet, 2020, vol. 395, no. 10227, pp. e49-e50. doi: 10.1016/S0140-6736(20)30493-1

17. The Novel Coronavirus Pneumonia Emergency Response Epidemiology Team. The epidemiological characteristics of an outbreak of 2019 novel coronavirus diseases COVID-19. China CCDC Weekly, 2020, vol. 2, no. 8, pp. 113-122. doi: 10.46234/ccdcw2020.032

18. Xiang F., Wang X., He X., He X., Peng Z., Yang B., Zhang J., Zhou Q., Ye H., Ma Y., Li H., Wei X., Cai P., Ma W.L. Antibody detection and dynamic characteristics in patients with COVID-19. Clin. Infect. Dis., 2020, vol. 71, no. 8, pp. 1930-1934. doi: 10.1093/ cid/ciaa461

19. Zhao J., Yuan Q., Wang H., Liu W., Liao X., Su Y., Wang X., Yuan J., Li T., Li J., Qian S., Hong C., Wang F., Liu Y., Wang Z., He Q., Li Z., He B., Zhang T., Fu Y., Ge S., Liu L., Zhang J., Xia N., Zhang Z. Antibody responses to SARS-CoV-2 in patients with novel coronavirus disease 2019. Clin. Infect. Dis., 2020, vol. 71, no. 16, pp. 2027-2034. doi: 10.1093/cid/ciaa344

\section{Авторы:}

Решетникова И.Д., к.м.Н., доцент, зам. директора по научной работе ФБУН Казанский НИИ эпидемиологии и микробиологии Роспотребнадзора, г. Казань, Россия; доцент кафедры фундаментальных основ клинической медицины, Казанский (Приволжский) федеральный университет, г. Казань, Россия;

Тюрин Ю.А., к.м.н., зав. лабораторией иммунологии и разработки аллергенов ФБУН Казанский НИИ эпидемиологии и микробиологии Роспотребнадзора, г. Казань, Россия; ассистент кафедры биохимии и клинической лабораторной диагностики ФГБОУ ВО Казанский государственный медицинский университет, г. Казань, Россия;

Агафонова Е.В., к.м.н., врач клинической лабораторной диагностики консультативно-диагностической поликлиники инфекционно-аллергических заболеваний ФБУН Казанский НИИ эпидемиологии и микробиологии Роспотребнадзора, г. Казань, Россия; ассистент кафедры пропедевтики детских болезней ФГБОУ ВО Казанский государственный медицинский университет, г. Казань, Россия;

Куликов С.Н., к.б.н., ведущий научный сотрудник лаборатории иммунологии и разработки аллергенов ФБУН Казанский НИИ эпидемиологии и микробиологии Роспотребнадзора, г. Казань, Россия;

Гилязутдинова Г.Ф., врач-эпидемиолог консультативнодиагностической поликлиники инфекционно-аллергических заболеваний ФБУН Казанский НИИ эпидемиологии и микробиологии Роспотребнадзора, г. Казань, Россия; Лопушов Д.В., к.М.н., доцент кафедры профилактической медицины и экологии человека ФГБОУ ВО Казанский государственный медицинский университет, г. Казань, Россия; доцент кафедры эпидемиологии и дезинфектологии, Казанская государственная медицинская академия - филиал ГБОУ дПО, г. Казань, Россия;

Шайхразиева Н.Д., к.м.н., доцент кафедры эпидемиологии и дезинфектологии Казанской государственной медицинской академии - филиала ГБОУ ДПО, г. Казань, Россия;

Исаева Г.Ш., д.м.Н., профессор, зам. директора по инновационному развитию ФБУН Казанский НИИ эпидемиологии и микробиологии Роспотребнадзора, г. Казань, Россия; зав. кафедрой микробиологии им. академика В.М. Аристовского ФГБОУ ВО Казанский государственный медицинский университет, г. Казань, Россия;

Зиатдинов В.Б., д.М.Н., директор ФБУН Казанский НИИ эпидемиологии и микробиологии Роспотребнадзора, г. Казань, Россия.

\author{
Authors: \\ Reshetnikova I.D., PhD (Medicine), Deputy Head of Kazan \\ Scientific Research Institute of Epidemiology and Microbiology \\ of Rospotrebnadzor, Kazan, Russian Federation; Associate \\ Professor, Department of Fundamental Clinical Medicine, Kazan \\ Federal University, Kazan, Russian Federation;
}

Tyurin Yu.A., PhD (Medicine), Head of Immunology Laboratory, Kazan Scientific Research Institute of Epidemiology and Microbiology of Rospotrebnadzor, Kazan, Russian Federation; Assistant Professor, Department of Biochemistry and Clinical Laboratory Diagnostics, Kazan State Medical University, Kazan, Russian Federation;

Agafonova E.V., PhD (Medicine), Laboratory Diagnostics

Doctor, Diagnostics Centre of Infection-Allergic Diseases, Kazan Scientific Research Institute of Epidemiology and Microbiology of Rospotrebnadzor, Kazan, Russian Federation; Assistant Professor, Department of Propedeutics of Child Diseases, Kazan State Medical University, Kazan, Russian Federation;

Kulikov S.N., PhD (Biology), Leading Researcher, Laboratory of Immunology and Allergens Development, Kazan Scientific Research Institute of Epidemiology and Microbiology of Rospotrebnadzor, Kazan, Russian Federation; Gilyazutdinova G.F., Epidemiologist, Diagnostics Centre of Infection-Allergic Diseases, Kazan Scientific Research Institute of Epidemiology and Microbiology of Rospotrebnadzor, Kazan, Russian Federation;

Lopushov D.V., PhD (Medicine), Associate Professor, Department of Preventive Medicine and Human Ecology, Kazan State Medical University, Kazan, Russian Federation; Associate Professor, Department of Epidemiology and Disinfectology, Kazan State Medical Academy, Kazan, Russian Federation;

Shaykhrazieva N.D., PhD (Medicine), Associate Professor, Department of Epidemiology and Desinfectology, Kazan State Medical Academy, Kazan, Russian Federation;

Isaeva G.Sh., PhD, MD (Medicine), Professor, Deputy Director for Innovative Development, Kazan Scientific Research Institute of Epidemiology and Microbiology of Rospotrebnadzor, Kazan, Russian Federation; Head of the Department of Microbiology named after Academician V.M. Aristovsky, Kazan State Medical Academy, Kazan, Russian Federation;

Ziatdinov V.B., PhD, MD (Medicine), Director of Kazan

Scientific Research Institute of Epidemiology and Microbiology of Rospotrebnadzor, Kazan, Russian Federation.

Received 17.08.2020

Revision received 27.03.202

Accepted 30.05.2021 